DOROTA SYLWESTRZAK

ORCID: 0000-0003-4985-2880

Uniwersytet Mikołaja Kopernika w Toruniu

d_sylwestrzak@wp.pl

\title{
Udział Rzecznika Małych i Średnich Przedsiębiorców w postępowaniu sądowoadministracyjnym
}

\begin{abstract}
Abstrakt: Działalność małych i średnich przedsiębiorców odgrywa istotną rolę w rozwoju przedsiębiorczości. Państwo podejmuje wiele działań zmierzających do ochrony ich praw na płaszczyźnie materialnoprawnej, proceduralnej oraz instytucjonalnej. Autorka w zwięzły sposób przedstawia uprawnienia Rzecznika Małych i Średnich Przedsiębiorców w postępowaniu przed sądami administracyjnymi. Dokonuje oceny wprowadzonych rozwiązań instytucjonalnych z punktu widzenia efektywności ochrony praw małych i średnich przedsiębiorców. W konkluzji utworzenie nowego podmiotu do ochrony małych i średnich przedsiębiorców autorka ocenia jako niecelowe, gdyż jego kompetencje i zadania stanowią powielenie uprawnień prokuratora i Rzecznika Praw Obywatelskich.
\end{abstract}

Słowa kluczowe: Rzecznik Małych i Średnich Przedsiębiorców, postępowanie sądowoadministracyjne, uprawnienia procesowe, wolność gospodarcza.

\section{Uwagi wstępne}

Wolność gospodarcza jest wartością tak istotną, że ustrojodawca zdecydował o zapewnieniu jej ochrony w ustawie zasadniczej ${ }^{1}$. W rozwoju polskiej gospodarki znaczącą rolę nadal odgrywa działalność prowadzona przez osoby fizyczne (mikro-, małe i średnie przedsiębiorstwa). Poprzednio obowiązująca ustawa

1 Art. 20 i 22 Konstytucji Rzeczypospolitej Polskiej z dnia 2 kwietnia 1997 roku, Dz.U. Nr 78, poz. 483 ze zm., dalej: Konstytucja RP. 
zawierała regulacje dotyczące wsparcia tak zwanej drobnej przedsiębiorczości². $\mathrm{Na}$ konieczność wdrożenia ułatwień w zakresie działalności gospodarczej prowadzonej przez mikro-, małych i średnich przedsiębiorców zwracano uwagę także w doktrynie ${ }^{3}$. Przełomowym rozwiązaniem miało być uchwalenie pakietu pięciu ustaw określanych jako konstytucja biznesu ${ }^{4}$. Na mocy art. 210 ust. 1 ustawy z dnia 6 marca 2018 roku - Przepisy wprowadzające ustawę - Prawo przedsiębiorców oraz inne ustawy dotyczące działalności gospodarczej ${ }^{5}$ wprowadzono nowe rozwiązanie o charakterze instytucjonalnym poprzez utworzenie Rzecznika Małych i Średnich Przedsiębiorców (dalej: RMŚP). Organ ten został utworzony w celu ochrony praw mikroprzedsiębiorców oraz małych i średnich przedsiębiorców, w tym czuwania nad poszanowaniem zasady wolności działalności gospodarczej, pogłębiania zaufania przedsiębiorców do władzy publicznej, bezstronności i równego traktowania, zrównoważonego rozwoju oraz zasady uczciwej konkurencji i poszanowania dobrych obyczajów oraz słusznych interesów przedsiębiorców (art. 1 ust. 1 u.r.m.ś.p.). Ustawa regulująca zagadnienia ustrojowe tego organu zawiera zaledwie 18 artykułów. W doktrynie pojawily się już stanowiska dotyczące zasadnych wątpliwości odnośnie do charakteru prawnego tego organu ${ }^{6}$. Ze wzgledu na brak jednoznacznych regulacji pojawiły się różne stanowiska. Podkreślano, że w przeciwieństwie do Rzecznika Praw Obywatel-

2 Art. 8 oraz rozdz. 7 ustawy z dnia 2 lipca 2004 roku o swobodzie działalności gospodarczej, tekst jedn. Dz.U. z 2017 r. poz. 168 ze zm., dalej: u.s.d.g.; obecnie nie obowiązuje.

3 D. Sylwestrzak, Mikroprzedsiębiorcy, mali i średni przedsiębiorcy, [w:] Rola państwa w procesach podnoszenia konkurencyjności i innowacyjności przedsiębiorstw. Diagnoza uwarunkowań $i$ barier prawnych - perspektywy rozwoju, red. A. Brzezińska-Rawa, Warszawa 2015, s. 57-68; A. Brzezińska-Rawa, D. Sylwestrzak, Uwagi i wnioski końcowe, [w:] Rola państwa w procesach..., s. 103-104; K. Kokocińska, Prawne aspekty wspierania rozwoju przedsiębiorczości - ustawa o swobodzie działalności gospodarczej oraz ustawy ustrojowo-kompetencyjne, „Ruch Prawniczy, Ekonomiczny i Socjologiczny" 2005, nr 4, s. 37 n.; eadem, Wspieranie rozwoju działalności gospodarczej w ujęciu zasad i wartości, „Ruch Prawniczy, Ekonomiczny i Socjologiczny” 2018, nr 4, s. 41-53.

${ }^{4}$ W skład konstytucji biznesu wchodzą: ustawa z dnia 6 marca 2018 roku - Prawo przedsiębiorców, tekst jedn. Dz.U. z 2019 r. poz. 1292, dalej: u.p.p.; ustawa z dnia 6 marca 2018 roku o Centralnej Ewidencji i Informacji o Działalności Gospodarczej i Punkcie Informacji dla Przedsiębiorcy, tekst jedn. Dz.U. z 2019 r. poz. 1291, dalej: u.c.e.i.d.g.; ustawa z dnia 6 marca 2018 roku o Rzeczniku Małych i Średnich Przedsiębiorców, Dz.U. z 2018 r. poz. 648, dalej: u.r.m.ś.p.; ustawa z dnia 6 marca 2018 roku o zasadach uczestnictwa przedsiębiorców zagranicznych i innych osób zagranicznych w obrocie gospodarczym na terytorium Rzeczypospolitej Polskiej, tekst jedn. Dz.U. 2019 r. poz. 1079 ze zm.; ustawa z dnia 6 marca 2018 roku — Przepisy wprowadzające ustawę - Prawo przedsiębiorców oraz inne ustawy dotyczące działalności gospodarczej, Dz.U. z 2018 r. poz. 650, dalej: przepisy wprowadzające. Przepisy tych aktów prawnych z uwzględnieniem wyjątków przewidzianych w ustawie co do zasady weszły w życie 30 kwietnia 2018 roku.

${ }^{5}$ Dz.U. z 2018 r. poz. 650. Uzasadnienie projektu ustawy o Rzeczniku Małych i Średnich Przedsiębiorców, druk nr 2052, Sejm RP VIII kadencji, s. 2, https://www.sejm.gov.pl/Sejm8.nsf/ PrzebiegProc.xsp?nr=2052 (dostęp: 19.09.2019). Tak też G. Lubeńczuk, [w:] M. Zdyb, G. Lubeńczuk, A. Wołoszyn-Cichocka, Prawo przedsiębiorców. Komentarz, Legalis 2019.

${ }^{6}$ P. Lissoń, Rzecznik Małych i Średnich Przedsiębiorców: Ombudsman czy organ administracji rzadowej?, „Ruch Prawniczy, Ekonomiczny i Socjologiczny” 2018, nr 4, s. 55-71; tak też 
skich (dalej: RPO) (art. 208 Konstytucji RP) ${ }^{7}$ czy też Rzecznika Praw Dziecka (dalej: RPD) (art. 72 ust. 4 Konstytucji RP) RMŚP nie jest organem konstytucyjnym powoływanym przez Sejm $\mathrm{RP}^{8}$. Rozważano, czy jest to centralny organ administracji rządowej ${ }^{9}$, czy też „organ hybrydowy — łączący cechy ombudsmana (o wyspecjalizowanych kompetencjach) i organu administracji rządowej"10. Zgodnie zakwalifikowano RMŚP do organów ochrony prawnej ${ }^{11}$, państwowego organu ochrony wolności i praw ${ }^{12}$. RMŚP może podejmować działania z urzędu bądź na wniosek przedsiębiorcy lub organizacji przedsiębiorców (art. 10 ust. 1 i 2 u.r.m.ś.p.). Ze względu na złożoność problematyki oraz związanie tematem problematyka charakteru prawnego nie będzie przedmiotem szerszych rozważań w niniejszym opracowaniu.

Analizie poddane zostaną zadania RMŚP wymienione w art. 8 u.r.m.ś.p. ${ }^{13}$ oraz kompetencje określone w art. 9 u.r.m.ś.p. ${ }^{14}$, z ograniczeniem do kompetencji

P. Ruczkowski w: L. Bielecki, P. Ruczkowski, Komentarz do ustawy o Rzeczniku Małych i Średnich Przedsiębiorców, [w:] Konstytucja biznesu. Komentarz, red. M. Wierzbowski, LEX 2019.

7 Wedhug L. Garlickiego Rzecznik Praw Obywatelskich jest „samodzielnym organem konstytucyjnym, organem ochrony prawnej" - idem, Polskie prawo konstytucyjne. Zarys wyktadu, Warszawa 2018, s. 442.

8 Tak P. Ruczkowski w: L. Bielecki, P. Ruczkowski, op. cit.; P. Lissoń, op. cit., s. 65-66.

9 P. Ruczkowski, [w:] L. Bielecki, P. Ruczkowski, op. cit.; P. Lissoń, op. cit., s. 66-67.

10 P. Lissoń, op. cit., s. 70.

11 Ibidem, s. 62.

12 Tak P. Ruczkowski w: L. Bielecki, P. Ruczkowski, op. cit.

13 Do zadań Rzecznika zgodnie z art. 8 u.r.m.ś.p. należy: 1. opiniowanie projektów aktów normatywnych dotyczących interesów przedsiębiorców oraz zasad podejmowania, wykonywania lub zakończenia działalności gospodarczej na terytorium Rzeczypospolitej Polskiej; 2. pomoc w organizacji mediacji między przedsiębiorcami a organami administracji publicznej; 3. współpraca z organizacjami pozarządowymi, społecznymi i zawodowymi, do których celów statutowych należy ochrona praw przedsiębiorców oraz współdziałanie ze stowarzyszeniami, ruchami obywatelskimi, innymi dobrowolnymi zrzeszeniami i fundacjami oraz z zagranicznymi i międzynarodowymi organami i organizacjami na rzecz ochrony praw przedsiębiorców oraz poszanowania zasady wolności działalności gospodarczej i równego traktowania; 4. inicjowanie i organizowanie działalności edukacyjnej i informacyjnej w zakresie związanym z wykonywaniem działalności gospodarczej na terytorium Rzeczypospolitej Polskiej, w szczególności w dziedzinie przedsiębiorczości oraz prawa gospodarczego; 5. podejmowanie innych działań, o których mowa w art. 9, o ile służą one ochronie praw przedsiębiorców.

14 Należą do nich między innymi występowanie do właściwych organów z wnioskami o podjęcie inicjatywy ustawodawczej albo wydanie lub zmianę innych aktów normatywnych w sprawach dotyczących działalności gospodarczej; występowanie do właściwych organów z wnioskiem o wydanie objaśnień prawnych, o których mowa w art. 33 ustawy z dnia 6 marca 2018 roku — Prawo przedsiębiorców, jeśli przepisy będące przedmiotem wniosku budzą wątpliwości w praktyce lub ich stosowanie wywołało rozbieżności w rozstrzygnięciach wydawanych przez właściwy organ administracji publicznej; informowanie właściwych organów nadzoru lub kontroli o dostrzeżonych nieprawidłowościach w funkcjonowaniu organów administracji publicznej; występowanie do właściwego ministra lub organu upoważnionego ustawowo do opracowywania i wnoszenia do rozpatrzenia przez Radę Ministrów projektów aktów normatywnych z wnioskiem, o którym mowa w art. 69 ust. 1 ustawy z dnia 6 marca 2018 roku - Prawo przedsiębiorców; występowanie do 
związanych z udziałem RMŚP w postępowaniu przed sądami administracyjnymi. Przedmiotem rozważań niniejszego opracowania będzie przede wszystkim analiza kompetencji RMŚP związanych z jego uprawnieniem do zainicjowania postępowania przed sądami administracyjnymi oraz udziałem $w$ tym postępowaniu, a zatem procesowych form aktywności właściwych stronie. Poza zakresem rozważań pozostaną inne formy aktywności RMŚP. Zasadniczym celem opracowania będzie ocena charakteru udziału RMŚP w postępowaniu sądowoadministracyjnym oraz próba oceny skuteczności przyjętych rozwiązań proceduralnych z punktu widzenia ochrony praw mikroprzedsiębiorców oraz małych i średnich przedsiębiorców.

\section{Rzecznik Małych i Średnich Przedsiębiorców jako uczestnik postępowania sądowoadministracyjnego}

W związku z uchwaleniem ustawy - Przepisy wprowadzające ustawę Prawo przedsiębiorców oraz inne ustawy dotyczące działalności gospodarczej znowelizowano także ustawę - Prawo o postępowaniu przed sądami administracyjnymi ${ }^{15}$, między innymi poprzez dodanie art. $8 \S 3$ p.p.s.a. ${ }^{16}$, zgodnie z którym RMŚP może wziąć udział w każdym toczącym się postępowaniu, a także wnieść skargę, skargę kasacyjną, zażalenie oraz skargę o wznowienie postępowania. RMŚP został zaliczony do podmiotów występujących w postępowaniu sądowoadministracyjnym oprócz stron postępowania, to jest skarżącego i organu, którego działanie, bezczynność lub przewlekłe postępowanie jest przedmiotem skargi (art. 32 p.p.s.a.). Powstaje pytanie, w jakim charakterze RMŚP będzie występować w postępowaniu sądowoadministracyjnym. Wydaje się, że z uwagi na zbliżony charakter prawny tego organu do prokuratora, RPO i RPD oraz przesądzenie w art. 9 pkt 8 u.r.m.ś.p. o tym, że RMŚP uczestniczy w postępowaniu sądowoadministracyjnym na prawach prokuratora, podmiot ten występować będzie w charakterze uczestnika postępowania, któremu przysługują prawa strony ${ }^{17}$.

Sądu Najwyższego z wnioskiem, o którym mowa w art. $83 \S 1$ ustawy z dnia 8 grudnia 2017 roku o Sądzie Najwyższym; wnoszenie skargi nadzwyczajnej na podstawie art. 89 § 2 ustawy z dnia 8 grudnia 2017 roku o Sądzie Najwyższym; żądanie wszczęcia przez uprawnionego oskarżyciela postępowania przygotowawczego w sprawach o przestępstwa wszczynane z urzędu; informowanie właściwych organów o dostrzeżonych barierach i utrudnieniach w zakresie wykonywania działalności gospodarczej na terytorium Rzeczypospolitej Polskiej.

15 Ustawa z dnia 30 sierpnia 2002 roku - Prawo o postępowaniu przed sądami administracyjnymi, tekst jedn. Dz.U. z 2018 r. poz. 1302 ze zm., dalej: p.p.s.a.

${ }^{16}$ Art. 79 pkt 1 przepisów wprowadzających.

17 M. Jaśkowska, D. Sylwestrzak, E. Kustra, Udziat prokuratora, Rzecznika Praw Obywatelskich oraz organizacji spolecznej w postępowaniu sadowoadministracyjnym, [w:] Podmioty admini- 
Podobnie jak pozostałe podmioty, czyli przede wszystkim prokurator, RPO, RPD czy organizacja społeczna działająca na rzecz osób trzecich, RMŚP występuje w postępowaniu sądowoadministracyjnym na prawach strony, w interesie innych osób, jako podmiot czynny ${ }^{18}$. Podmiot ten nie jest stroną postępowania sądowoadministracyjnego, „uzyskuje on wyłącznie prawa strony” ${ }^{19}$. Do takich uprawnień strony należy między innymi prawo do wnoszenia określonych środków zaskarżenia, takich jak skarga, skarga kasacyjna, zażalenie, skarga o wznowienie postępowania bądź też prawo do udziału w toczącym się postępowaniu sądowoadministracyjnym niezależnie od jego stadium.

RMŚP działa w interesie publicznym i jednostek (ogólnym) ze względu na ochronę praw mikroprzedsiębiorcy, małego lub średniego przedsiębiorcy ${ }^{20}$. Z tego wynika, że RMŚP może wystąpić w roli skarżącego, może także przyłączyć się do toczącego się postępowania sądowoadministracyjnego, zgłaszając swój udział w sprawie na każdym etapie postępowania. Niemniej jednak należy podkreślić, że jego udział $\mathrm{w}$ postępowaniu sądowoadministracyjnym będzie ograniczony wyłącznie do spraw, w których mogą zostać naruszone prawa mikro-, małego lub średniego przedsiębiorcy. Wydaje się, że ze względu na ograniczenie zakresu spraw, w których RMŚP może wziąć udział w postępowaniu sądowoadministracyjnym, nie będzie on posiadał tak szerokich uprawnień uczestnictwa w postępowaniu sądowoadministracyjnym, jakie w ocenie autorki przyznano prokuratorowi i RPO. Podmioty te bowiem występują w interesie publicznym ze względu na ochronę zasady praworządności działania organów administracji publicznej oraz ochronę prawa i wolności jednostki zawartych w Konstytucji RP ${ }^{21}$. Legitymacja RMŚP do wniesienia skargi (art. 8 i art. $50 \S 1$ p.p.s.a.), podobnie jak prokuratora czy RPO, ma charakter formalny ${ }^{22}$, a nie materialny, dlatego też nie musi on wykazywać „związku materialno-prawnego wynikającego z zaskarżonego aktu normatywnego $\mathrm{z}$ odpowiednimi przepisami prawnymi, które regulują sytuację prawną obywateli, na rzecz których wniesiono skargę"23. W doktrynie prezen-

stracji publicznej i prawne formy ich działania. Studia i materiały z Konferencji Naukowej poświęconej Jubileuszowi 80-tych urodzin Profesora Eugeniusza Ochendowskiego, Torun 2005, s. 225.

18 J. Zimmermann, Prawo administracyjne, Warszawa 2018, s. 490.

19 M. Masternak, [w:] M. Jaśkowska, M. Masternak, E. Ochendowski, Postępowanie sądowoadministracyjne, Warszawa 2004, s. 87.

20 J. Drachal, J. Jagielski, M. Cherka, [w:] Prawo o postępowaniu przed sqdami administracyjnymi. Komentarz, red. R. Hauser, M. Wierzbowski, Legalis 2019.

21 Zob. wyroki WSA w Lublinie z dnia: 17 maja 2018 roku, III SA/Lu 79/18, LEX nr 2500984, 17 grudnia 2013 roku, II SA/Lu 438/13, LEX nr 1444522. Por. A. Kabat, [w:] B. Dauter, A. Kabat, M. Niezgódka-Medek, Prawo o postępowaniu przed sądami administracyjnymi. Komentarz, LEX 2018.

${ }^{22}$ H. Knysiak-Sudyka, Skarga i skarga kasacyjna w postępowaniu sądowoadministracyjnym. Komentarz i orzecznictwo, LEX 2018.

${ }^{23}$ Wyrok NSA z dnia 5 czerwca 2012 roku, II OSK 747/12, LEX nr 1215573. Tak też T. Woś, [w:] Prawo o postępowaniu przed sądami administracyjnymi. Komentarz, red. T. Woś, H. Knysiak-Molczyk, M. Romańska, LEX 2016. 
towane są różne stanowiska odnośnie do oceny podstaw legitymacji procesowej prokuratora i RPO. Część przedstawicieli doktryny uważa, że legitymacja procesowa tych podmiotów jest zróżnicowana i powinna być oceniania przez pryzmat zadań i kompetencji przez nie realizowanych ${ }^{24}$. Inni z kolei uważają, że legitymacja prokuratora i RPO jest zbliżona ${ }^{25}$. Ze względu na to wątpliwości budzi kwestia oceny podstaw legitymacji RMŚP. Wydaje się, że aktualny jest podgląd, że RMŚP, podobnie jak prokurator czy RPO, czy też RPD, będzie decydować samodzielnie o przyłączeniu się do toczącego się postępowania sądowoadministracyjnego i nie będzie to podlegać ocenie sądu ${ }^{26}$. Podmioty te, wnosząc skargę do sądu administracyjnego, nie mają bowiem „obowiązku wykazania naruszenia interesu prawnego określonej jednostki bądź interesu społecznego" 27 . Należy przyjąć, że sąd administracyjny kwestię legitymacji procesowej RMŚP będzie oceniać przez pryzmat dopuszczalności oraz zasadności skargi do sądu administracyjnego ${ }^{28}$.

\section{Uprawnienia procesowe Rzecznika Małych i Średnich Przedsiębiorców w postępowaniu sądowoadministracyjnym}

RMŚP przysługuje prawo do wniesienia skargi w świetle art. $50 \S 1$ p.p.s.a. Uprawnienia RMŚP przedstawiają się jednak odmiennie do uprawnień strony postępowania sądowoadministracyjnego. Różnice dotyczą między innymi zwolnienia z obowiązku wyczerpania środków zaskarżenia, chyba że RMŚP brał udział w postępowaniu administracyjnym na prawach strony ${ }^{29}$. Kolejna różnica odnosi się do terminu wniesienia skargi, który dla RMŚP jest wydłużony i wynosi sześć miesięcy od dnia doręczenia stronie rozstrzygnięcia w sprawie indywidualnej, a w pozostałych przypadkach sześć miesięcy od dnia wejścia w życie aktu lub podjęcia innej czynności uzasadniającej wniesienie skargi (art. 53 § 3 p.p.s.a.).

24 T. Woś, op. cit.; E. Bojanowski, [w:] E. Bojanowski, Z. Cieślak, J. Lang, Postępowanie administracyjne i postepowanie przed sądami administracyjnymi, Warszawa 2004, s. 241.

25 A. Wróbel, [w:] K. Chorąży, W. Taras, A. Wróbel, Postępowanie administracyjne, egzekucyjne i sądowoadministracyjne, Kraków 2003, s. 305; B. Adamiak, [w:] B. Adamiak, J. Borkowski, Postępowanie administracyjne i sądowoadministracyjne, Warszawa 2007, s. 428-429.

26 Wyrok WSA w Gdańsku z dnia 19 stycznia 2017 roku, III SA/Gd 1009/16, LEX nr 2204798; J.P. Tarno, Prawo o postepowaniu przed sadami administracyjnymi. Komentarz, Warszawa 2012, s. 64-65.

27 Wyrok WSA w Lublinie z dnia 17 maja 2018 roku, III SA/Lu 79/18, LEX nr 2500984.

28 M. Jaśkowska, D. Sylwestrzak, E. Kustra, op. cit., s. 229-230.

29 H. Knysiak-Sudyka, op. cit.; postanowienie WSA w Rzeszowie z dnia 9 maja 2011 roku, II SAB/Rz 12/11, Legalis nr 866871; wyrok WSA w Warszawie z dnia 14 grudnia 2017 roku, VIII SA/Wa 460/17, LEX nr 2419216. 
Termin sześciomiesięczny nie ma zastosowania w sprawach innych aktów określonych $w$ art. $53 \S 2$ a p.p.s.a., to jest aktów prawa miejscowego jednostek samorządu terytorialnego i terenowych organów administracji rządowej oraz innych uchwał (zarządzeń) organów jednostek samorządu terytorialnego ${ }^{30}$.

Uprzywilejowanie podmiotów działających na prawach strony przejawia się także w odniesieniu do wymogów fiskalnych pism procesowych, gdyż są one zwolnione z mocy prawa z obowiązku uiszczania kosztów sądowych (art. 239 § 1 pkt 2 p.p.s.a.), na które składają się opłaty sądowe oraz wydatki. Ustawodawca wprost nie wymienia RMŚP $\mathrm{w}$ art. 239 § 1 pkt 2 p.p.s.a., jednakże z uwagi na to, że występuje on w postępowaniu sądowoadministracyjnym na podobnych zasadach jak prokurator, zwolnienie z mocy prawa z obowiązku uiszczania kosztów odnosi się też do niego ${ }^{31}$.

RMŚP został uprawniony także do wniesienia na podstawie art. $173 \S 2$ p.p.s.a. skargi kasacyjnej od wyroku wojewódzkiego sądu administracyjnego oraz postanowień kończących postępowanie w sprawie. Termin do wniesienia skargi kasacyjnej wynosi 30 dni od doręczenia stronie odpisu orzeczenia z uzasadnieniem, jednakże w sytuacji gdy stronie nie doręcza się orzeczenia, RMŚP może w terminie trzydziestu dni od dnia wydania orzeczenia wystąpić o sporządzenie uzasadnienia orzeczenia i wnieść skargę kasacyjną w terminie trzydziestu dni od dnia doręczenia odpisu orzeczenia z uzasadnieniem (art. $177 \S 2$ p.p.s.a.). Sporządzenie skargi kasacyjnej jest objęte przymusem adwokacko-radcowskim. Powstaje pytanie, czy obowiązek ten odnosi się również do RMŚP. W odniesieniu do prokuratora, RPO, RPD w doktrynie i orzecznictwie prezentowano stanowisko, że przymus adwokacko-radcowski nie obejmuje tych podmiotów ${ }^{32}$. W ocenie autorki omawiane rozwiązanie prawne odnosi się także do RMŚP.

Ponadto RMŚP na podstawie art. 8 § 3 p.p.s.a. został uprawniony do złożenia zażalenia na postanowienia wymienione w art. $194 \S 1$ p.p.s.a. oraz niewymienione w tym artykule. Kolejnym uprawnieniem jest wyposażenie RMŚP w prawo do złożenia nadzwyczajnego środka - skargi o wznowienie postępowania (art. 8 § 3 w zW. z art. 271-274 p.p.s.a.). W postępowaniu ze skargi o wznowienie postępowania stosuje się odpowiednio przepisy o postępowaniu przed sądem pierwszej instancji (art. 276 p.p.s.a.).

W wypadku przystąpienia RMŚP do postępowania przed sądem administracyjnym poprzez wniesienie skargi do wojewódzkiego sądu administracyjnego czy też złożenia środków zaskarżenia (skargi kasacyjnej, zażalenia, skargi o wzno-

30 J.P. Tarno, op. cit., s. 184; H. Knysiak-Sudyka, op. cit.; wyrok NSA z dnia 18 stycznia 2005 roku, GSK 1258/04, Legalis nr 71639.

31 Uchwała NSA w składzie siedmiu sędziów z dnia 3 lipca 2017 roku, I OPS 1/17, ONSAiWSA 2017/6/95.

32 Wyrok NSA z dnia 31 maja 2005 roku, II GSK/57/05, ONSAiWSA 2006/1/109; H. Knysiak-Sudyka, [w:] Prawo o postępowaniu przed sądami administracyjnymi. Komentarz, red. T. Woś, H. Knysiak-Molczyk, M. Romańska, LEX 2016. 
wienie postępowania) bądź złożenia oświadczenia o przystąpieniu do toczącego się przed sądem administracyjnym postępowania uzyskuje on „status uczestnika na prawach strony"33. Z uwagi na dużą dyspozycyjność w zakresie wzięcia udziału w postępowaniu sądowoadministracyjnym może on także wystąpić ze sprawy. Przyjmuje się, że takie oświadczenie ma charakter wiążący dla sądu ${ }^{34}$. Sąd nie ma bowiem możliwości wzywania RMŚP do osobistego stawiennictwa ${ }^{35}$. Zasadniczo jego nieobecność na rozprawie, stosownie do art. $92 \S 2$ p.p.s.a., nie wstrzymuje rozpoznania sprawy przez sąd, niemniej jednak, jak słusznie zauważa się w doktrynie, zaniechanie zawiadomienia RMŚP o terminie posiedzenia może być zakwalifikowane jako podstawa kasacyjna $\mathrm{z}$ art. 174 pkt 2 p.p.s.a., w sytuacji gdy mogło to mieć istotny wpływ na wynik sprawy ${ }^{36}$.

Kolejne kontrowersje może budzić kwestia wpływu wyłączenia jawności posiedzenia przed sądem na uprawnienia RMŚP. Wydaje się, że z uwagi na treść przepisu art. $97 \S 1$ p.p.s.a. RMŚP, podobnie jak prokurator, PRO czy też RPD, mimo wyłączenia jawności posiedzenia, może brać w nim udział ${ }^{37}$.

RMŚP stosownie do przepisu art. $264 \S 2$ p.p.s.a. został uprawniony również do zainicjowania podjęcia uchwały przez Naczelny Sąd Administracyjny, mającej na celu wyjaśnienie przepisów prawnych, których stosowanie wywołało rozbieżności w orzecznictwie sądów administracyjnych. Z tego wynika, że uprawnienie związane z działalnością uchwałodawczą sądów administracyjnych nie obejmuje prawa do zainicjowania podjęcia uchwał konkretnych ${ }^{38}$. Uchwały konkretne podejmowane są na podstawie postanowienia składu orzekającego NSA. W doktrynie rozważany był problem udziału prokuratora i RPO w posiedzeniach NSA, podczas których podejmowane są uchwały NSA abstrakcyjne i konkretne. Przyjęto, że oba podmioty mogą brać udział w posiedzeniach NSA, przy czym w odniesieniu do prokuratora kompetencje te zostały przyznane organom określonego szczebla $^{39}$. W art. 265 p.p.s.a. ustawodawca wprowadził obowiązek udziału Prokuratora Generalnego albo jego zastępcy w posiedzeniu całego składu NSA lub też w posiedzeniu danej Izby NSA, którego przedmiotem jest podjęcie uchwały abstrakcyjnej bądź uchwały konkretnej. Obowiązkowy udział przewidziano także w posiedzeniu składu siedmiu sędziów NSA dla prokuratora Prokuratury Krajowej lub prokuratora innej jednostki organizacyjnej prokuratury, delegowanego do wykonywania czynności w Prokuraturze Krajowej i wyznaczonego przez Prokuratora Generalnego lub jego zastępcę do udziału w posiedzeniach Naczelnego Sądu

33 J.P. Tarno, op. cit., s. 278.

34 M. Jaśkowska, D. Sylwestrzak, E. Kustra, op. cit., s. 235.

35 B. Dauter, [w:] B. Dauter, A. Kabat, M. Niezgódka-Medek, op. cit.

36 J.P. Tarno, op. cit., s. 278; B. Dauter, op. cit.

37 M. Jagielska, A. Wiktorowska, K. Zalasińska, [w:] Prawo o postępowaniu przed sądami administracyjnymi. Komentarz, red. R. Hauser, M. Wierzbowski, Legalis 2019.

38 J.P. Tarno, op. cit., s. 662.

39 M. Jaśkowska, D. Sylwestrzak, E. Kustra, op. cit., s. 236. 
Administracyjnego. Ze względu na to w ocenie autorki RMŚP będzie uprawniony do udziału w posiedzeniu NSA, którego przedmiotem będzie podjęcie uchwały abstrakcyjnej. Jego udział w przeciwieństwie do podmiotów wymienionych w art. 265 p.p.s.a. nie będzie mieć charakteru obligatoryjnego, a co za tym idzie — jego nieobecność nie będzie stanowić przeszkody do odbycia posiedzenia lub podstawy do odroczenia posiedzenia.

Z udziałem RMŚP w postępowaniu sądowoadministracyjnym wiąże się kolejny problem, dotyczący mianowicie instytucji wyłączenia (art. 24 p.p.s.a.). Przepis art. 24 p.p.s.a. stanowi wyłącznie o prokuratorze. W doktrynie zaprezentowano pogląd, zgodnie z którym jeżeli uczestnik na prawach strony bierze udział w postępowaniu sądowoadministracyjnym na takich prawach jak prokurator, instytucja wyłączenia będzie mieć odpowiednie zastosowanie ${ }^{40}$. Z uwagi na to, że RMŚP bierze udział w postępowaniu przed sądami administracyjnymi na takich prawach jak prokurator, zgodnie z art. 9 ust. 1 pkt 8 u.r.m.ś.p. przepisy dotyczące wyłączenia będą miały zastosowanie także do niego.

\section{Wnioski}

Wolność gospodarcza i wolna konkurencja to dobra konstytucyjnie chronione. Rozwój społecznej gospodarki rynkowej powoduje powstawanie nowych zjawisk społeczno-gospodarczych, które nie zawsze korzystnie wpływają na gospodarkę. Mogą one naruszać zasady wolności działalności gospodarczej, uczciwej konkurencji i poszanowania dobrych obyczajów oraz słusznych interesów innych przedsiębiorców i konsumentów. Negatywne zjawiska gospodarcze wymagają stworzenia stosownych gwarancji ustrojowych, proceduralnych oraz materialnoprawnych.

Niewątpliwie w Polsce nadal gospodarka oparta jest na działalności mikro-, małych i średnich przedsiębiorców, dlatego też za celowe należy uznać podejmowanie działań służących ułatwianiu podejmowania i prowadzenia działalności przez te podmioty. Sytuacja prawna mikro-, małych i średnich przedsiębiorców, w szczególności osób fizycznych prowadzących działalność gospodarczą, w pewnym sensie jest zbliżona do sytuacji konsumenta jako „słabszej strony stosunków obrotu gospodarczego" 41 . W ujęciu instytucjonalnym ochrona konsumentów należy do zadań wielu organów administracji publicznej oraz instytucji, na przykład

40 Ibidem, s. 237.

41 SN w wyroku z dnia 18 lipca 2019 roku, I CSK 587/17, Legalis nr 2235948, stwierdził, że „osoba fizyczna samodzielnie zarządzająca swoim majątkiem przez inwestowanie posiadanych środków (oszczędności) w instrumenty finansowe (w tym nabywanie oraz sprzedaż akcji i udziałów) w celu niezwiązanym bezpośrednio z jej działalnością gospodarczą lub zawodową jest konsumentem". 
Prezesa Urzędu Ochrony Konkurencji i Konsumentów, Prezesa Urzędu Regulacji Energetyki, Prezesa Urzędu Komunikacji Elektronicznej, Rzecznika Finansowego, Powiatowego (Miejskiego) Rzecznika Praw Konsumentów.

Powstaje pytanie, czy tworzenie nowych organów obok już funkcjonujących przyczyni się do rozwoju oraz ochrony praw mikro-, małych i średnich przedsiębiorców. Należy przyjąć, że w zakresie, w jakim danego przedsiębiorcę można zakwalifikować jako konsumenta, jego interesy chronione są przez już funkcjonujące organy regulacyjne, Rzecznika Finansowego, Powiatowego (Miejskiego) Rzecznika Praw Konsumentów. Konstytucyjny organ - RPO — odgrywa istotną rolę $\mathrm{w}$ zakresie ochrony praw i wolności konstytucyjnych, w tym wolności gospodarczej, działa w interesie publicznym, a zatem i na rzecz mikro-, małych i średnich przedsiębiorców. Działalność prokuratora na rzecz ochrony praworządności, a zatem dbałości także o przestrzeganie zasady wolności działalności gospodarczej i wolnej konkurencji, wydaje się również wystarczać. Czy rzeczywiście utworzenie nowego organu - RMŚP — będzie sprzyjać ochronie mikro-, małych i średnich przedsiębiorców, czy będzie to powielanie kompetencji i ochrona iluzoryczna?

Analiza wybranych uprawnień proceduralnych RMŚP w postępowaniu sądowoadministracyjnym prowadzi do następujących konkluzji. Po pierwsze, należy zauważyć, że aksjologiczną podstawą leżącą u podstaw legitymacji skargowej RMŚP jest interes ogólny, służący ochronie wartości o szczególnej doniosłości dla społeczeństwa. Ocena legitymacji procesowej RMŚP będzie dokonywana z punktu widzenia realizowanych przez niego zadań i kompetencji, do których niewątpliwie należy zaliczyć ochronę praw mikroprzedsiębiorcy, małego lub średniego przedsiębiorcy (art. $8 \S 3$ p.p.s.a.). Niewątpliwie ustalenia poczynione wcześniej w niniejszym opracowaniu pozwalają na przyjęcie, że udział RMŚP na prawach strony w postępowaniu sądowoadministracyjnym wykazuje pewne zróżnicowanie w odniesieniu do prokuratora czy też RPO. W ocenie autorki, mimo że RMŚP działa także w interesie ogólnym i ustawodawca przesądził, że występuje on na prawach prokuratora, jego możliwości uczestnictwa na prawach strony są zdecydowanie węższe aniżeli prokuratora oraz RPO. Ochrona praw mikroprzedsiębiorcy, małego lub średniego przedsiębiorcy mieści się w ochronie praw człowieka i obywatela oraz praworządności, na straży której stoją prokurator i RPO. Mając na uwadze wcześniejsze ustalenia co do udziału RMŚP w postępowaniu sądowoadministracyjnym, należy krytycznie ocenić tworzenie nowych instytucji obok już funkcjonujących. Dotychczasowe rozwiązania proceduralne, w szczególności ochrona sądowoadministracyjna, spełniały swoją rolę w zakresie ochrony praw mikroprzedsiębiorcy, małego lub średniego przedsiębiorcy, dlatego też w ocenie autorki jako całkowicie chybione należy ocenić utworzenie nowego organu - RMŚP. Jego rola w postępowaniu sądowoadministracyjnym będzie miała charakter iluzoryczny. Dotychczasowa działalność wskazuje, że organ ten nie występował w postępowaniu sądowoadministracyjnym, a jego aktywność ograniczała się wyłącznie do opiniowania 
kilku ustaw, kierowania spraw do rozpoznania przez właściwe organy, kierowania wniosków o wydanie tak zwanych objaśnień prawnych ${ }^{42}$.

\section{Bibliografia}

Adamiak B., [w:] B. Adamiak, J. Borkowski, Postępowanie administracyjne i saqdowoadministracyjne, Warszawa 2007.

Bielecki L., Ruczkowski P., Komentarz do ustawy o Rzeczniku Małych i Średnich Przedsiębiorców, [w:] Konstytucja biznesu. Komentarz, red. M. Wierzbowski, LEX 2019.

Bojanowski E., [w:] E. Bojanowski, Z. Cieślak, J. Lang, Postępowanie administracyjne i postępowanie przed sadami administracyjnymi, Warszawa 2004.

Brzezińska-Rawa A., Sylwestrzak D., Uwagi i wnioski końcowe, [w:] Rola państwa w procesach podnoszenia konkurencyjności i innowacyjności przedsiębiorstw. Diagnoza uwarunkowań i barier prawnych - perspektywy rozwoju, red. A. Brzezińska-Rawa, Warszawa 2015.

Dauter B., [w:] B. Dauter, A. Kabat, M. Niezgódka-Medek, Prawo o postępowaniu przed sądami administracyjnymi. Komentarz, LEX 2018.

Drachal J., Jagielski J., Cherka M., [w:] Prawo o postepowaniu przed sadami administracyjnymi. Komentarz, red. R. Hauser, M. Wierzbowski, Legalis 2019.

Garlicki L., Polskie prawo konstytucyjne. Zarys wyktadu, Warszawa 2018.

Jagielska M., Wiktorowska A., Zalasińska K. [w:] Prawo o postępowaniu przed sądami administracyjnymi. Komentarz, red. R. Hauser, M. Wierzbowski, Legalis 2019.

Jaśkowska M., Sylwestrzak D., Kustra E., Udział prokuratora, Rzecznika Praw Obywatelskich oraz organizacji spolecznej w postepowaniu sądowoadministracyjnym, [w:] Podmioty administracji publicznej i prawne formy ich działania. Studia i materiały z Konferencji Naukowej poświęconej Jubileuszowi 80-tych urodzin Profesora Eugeniusza Ochendowskiego, Toruń 2005.

Kabat A., [w:] B. Dauter, A. Kabat, M. Niezgódka-Medek, Prawo o postępowaniu przed sądami administracyjnymi. Komentarz, LEX 2018.

Knysiak-Sudyka H., Skarga i skarga kasacyjna w postępowaniu sądowoadministracyjnym. Komentarz i orzecznictwo, LEX 2018.

Knysiak-Sudyka H., [w:] Prawo o postępowaniu przed sadami administracyjnymi. Komentarz, red. T. Woś, H. Knysiak-Molczyk, M. Romańska, LEX 2016.

Kokocińska K., Prawne aspekty wspierania rozwoju przedsiębiorczości - ustawa o swobodzie dziatalności gospodarczej oraz ustawy ustrojowo-kompetencyjne, „Ruch Prawniczy, Ekonomiczny i Socjologiczny" 2005, $\mathrm{nr} 4$.

Kokocińska K., Wspieranie rozwoju działalności gospodarczej w ujęciu zasad $i$ wartości, „Ruch Prawniczy, Ekonomiczny i Socjologiczny" 2018, nr 4.

Lissoń P., Rzecznik Małych i Średnich Przedsiębiorców: Ombudsman czy organ administracji rządowej?, „Ruch Prawniczy, Ekonomiczny i Socjologiczny” 2018, nr 4.

Lubeńczuk G., [w:] M. Zdyb, G. Lubeńczuk, A. Wołoszyn-Cichocka, Prawo przedsiębiorców. Komentarz, Legalis 2019.

Masternak M., [w:] M. Jaśkowska, M. Masternak, E. Ochendowski, Postępowanie sądowoadministracyjne, Warszawa 2004.

Sylwestrzak D., Mikroprzedsiębiorcy, mali i średni przedsiębiorcy, [w:] Rola państwa w procesach podnoszenia konkurencyjności i innowacyjności przedsiębiorstw. Diagnoza uwarunkowań i barier prawnych - perspektywy rozwoju, red. A. Brzezińska-Rawa, Warszawa 2015.

42 https://rzecznikmsp.gov.pl/dokumenty/ (dostęp: 29.09.2019). 
Tarno J.P., Prawo o postępowaniu przed sądami administracyjnymi. Komentarz, Warszawa 2012.

Woś T., [w:] Prawo o postępowaniu przed sądami administracyjnymi. Komentarz, red. T. Woś, H. Knysiak-Molczyk, M. Romańska, LEX 2016.

Wróbel A., [w:] K. Chorąży, W. Taras, A. Wróbel, Postępowanie administracyjne, egzekucyjne i sqdowoadministracyjne, Kraków 2003.

Zimmermann J., Prawo administracyjne, Warszawa 2018.

\section{Participation of the Ombudsman for Small and Medium-Sized Enterprises in the administrative court proceedings}

\section{Summary}

The activity of small and medium-sized enterprises plays an important role in the development of entrepreneurship. The state undertakes a number of actions aimed at protecting their rights on the material, procedural and institutional level. The author briefly presents the rights of the Ombudsman for Small and Medium-Sized Enterprises in proceedings before administrative courts. The introduced institutional solutions from the point of view of the effectiveness of protection of the rights of small and medium enterprises are evaluated. In conclusion, the author considers the creation of a new entity for the protection of small and medium enterprises to be pointless, because its competences and tasks are a duplication of the powers of the prosecutor and the Ombudsman.

Keywords: Ombudsman for Small and Medium-Sized Enterprises, administrative court proceedings, procedural rights, economic freedom. 